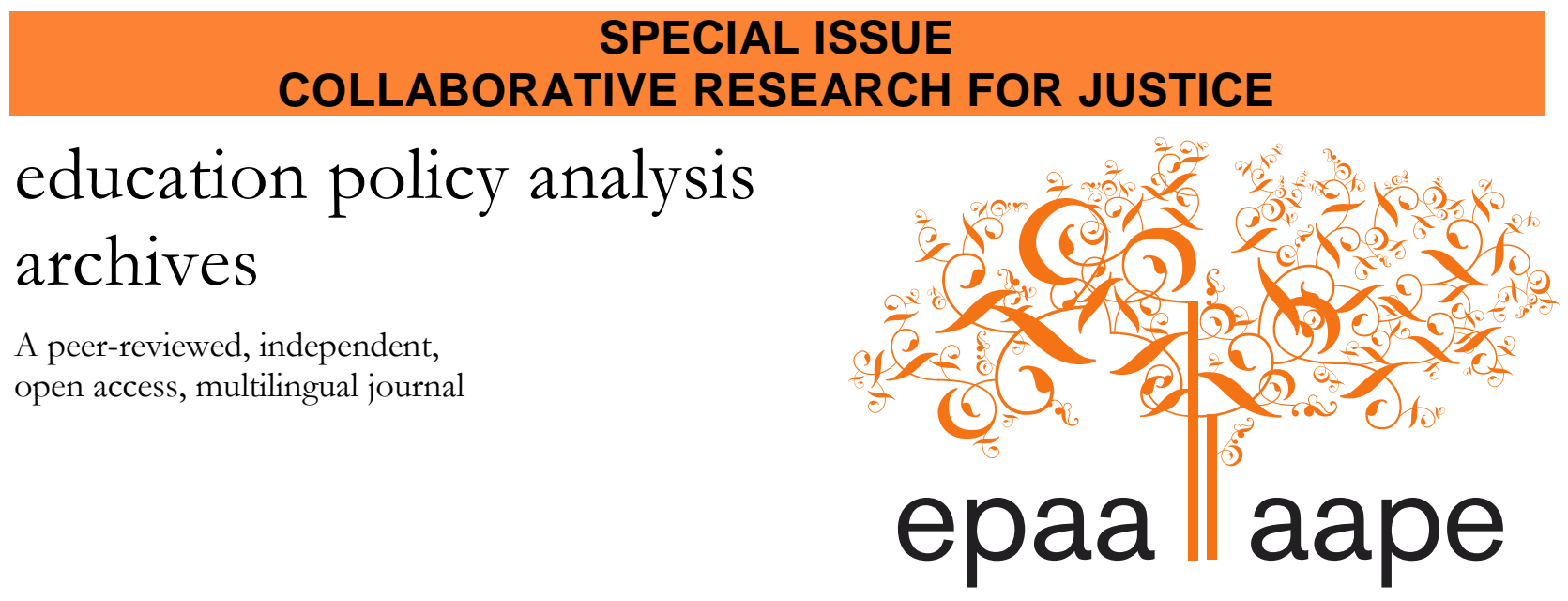

Arizona State University

Volume 27 Number 54

May 20, 2019

ISSN 1068-2341

\title{
Amplifying Youth Voice and Cultivating Leadership through Participatory Action Research
}

\author{
Rachele Gardner \\ William M. Snyder \\ \& \\ Ayda Zuguy \\ Youth Hub Boston \\ United States
}

Citation: Gardner, R., Snyder, W., \& Zuguy, A. (2019). Amplifying youth voice and cultivating leadership through participatory action research. Education Policy Analysis Archives, 27(54). http://dx.doi.org/10.14507/epaa.27.2621 This article is part of the special issue, Collaborative Research for Justice and Multi-Issue Movement Building, guest edited by Ronald D. Glass \& Mark R. Warren.

Abstract: This article presents the story of Youth Hub, a grassroots, neighborhood-based initiative in Boston, Massachusetts, highlighting its use of participatory action research (PAR) to amplify youth voice, cultivate leadership, and promote change. The article includes an explanation of the need from which Youth Hub emerged; a discussion of Youth Hub's use of PAR, including benefits and challenges of the approach; a summary of key research findings; an examination of PAR's usefulness for knowledge creation, including benefits and challenges; and an analysis of youth leadership and ownership in Youth Hub's model, also including benefits and challenges. The article concludes with 
suggestions for how Youth Hub's approach can be useful for amplifying youth voice and building youth leadership more broadly.

Keywords: youth voice; youth leadership; Boston

\section{Ampliando la voz de los jóvenes y cultivando el liderazgo a través de la investigación de acción participativa}

Resumen: Este artículo presenta la historia de Youth Hub, una iniciativa comunitaria basada en el vecindario en Boston, Massachusetts, que destaca el uso de la investigación de acción participativa (PAR) para amplificar la voz de los jóvenes, cultivar el liderazgo y promover el cambio. El artículo incluye una explicación de la necesidad de la que surgió Youth Hub; una discusión sobre el uso del PAR por parte de los jóvenes, incluidos los beneficios y desafíos del enfoque; un resumen de los hallazgos clave de la investigación; un examen de la utilidad del PAR para la creación de conocimiento, incluidos los beneficios y desafíos; y un análisis del liderazgo y la apropiación de los jóvenes en el modelo de Youth Hub, que también incluye beneficios y desafíos. El artículo concluye con sugerencias sobre cómo el enfoque de Youth Hub puede ser útil para amplificar la voz de los jóvenes y desarrollar el liderazgo juvenil de manera más amplia.

Palabras-clave: voz juvenil; liderazgo juvenil; Bostón

\section{Ampliando a voz da juventude e cultivando a liderança por meio de pesquisa-ação participativa}

Resumo: Este artigo apresenta a história do Youth Hub, uma iniciativa de base em Boston, Massachusetts, destacando o uso da Pesquisa de Ação Participativa (PAR) para ampliar a voz dos jovens, cultivar liderança e promover mudanças. O artigo inclui uma explicação da necessidade de que o Hub da Juventude surgiu; uma discussão sobre o uso do PAR da Youth Hub, incluindo benefícios e desafios da abordagem; um resumo dos principais resultados da pesquisa; um exame da utilidade do PAR para a criação de conhecimento, incluindo benefícios e desafios; e uma análise da liderança e apropriação de jovens no modelo Youth Hub, incluindo também benefícios e desafios. O artigo conclui com sugestões de como a abordagem do Centro da Juventude pode ser útil para ampliar a voz dos jovens e construir a liderança dos jovens de forma mais ampla.

Palavras-chave: voz juvenil; liderança juvenil; Boston 


\section{Introduction}

Youth Hub is a grassroots, neighborhood-based initiative in Boston, Massachusetts, with a mission to "catalyze, equip, and empower a youth-driven and collaborative movement to eliminate barriers to success for youth of color in Boston's neighborhoods and beyond." Youth Hub's vision is for all youth to have the resources, opportunities, and support to succeed, and the group strives to address the many barriers - low employment, underperforming schools, lack of opportunity, poverty, trauma, violence, and more - that get in the way for low-income and youth of color. With a belief that many of the solutions lie in developing the power and voice of youth themselves, Youth Hub applies a Youth-Led model of Participatory Action Research to develop young leaders and improve youth outcomes. Youth Hub combines training and hands-on experience in community organizing, civic engagement, participatory action research, innovation methods, data analysis, career exploration, and soft skill development to equip young people for personal success and as leaders in transforming their communities. Young leaders work in collaboration with businesses, government, and other community stakeholders to identify and creatively address critical youth needs. This youth-driven model informs businesses and government through research and technology, innovates solutions to existing or emerging problems, and influences policy for sustained change on issues that affect youth.

This article will recount Youth Hub's story, highlighting its use of participatory action research (PAR) to amplify youth voice, cultivate leadership, and promote change. The article includes an explanation of the need from which Youth Hub emerged; a discussion of Youth Hub's use of PAR, including benefits and challenges of the approach; a summary of key research findings; an examination of PAR's usefulness for knowledge creation, including benefits and challenges; and an analysis of youth leadership and ownership in Youth Hub's model, including benefits and challenges. Finally, the conclusion will tie these aspects together and suggest ways Youth Hub's approach can be useful for amplifying youth voice and building youth leadership more broadly.

\section{The Need}

Youth Hub is located in Codman Square, the geographic center of Dorchester, which is the largest of Boston's 23 neighborhoods. While Dorchester is a racially and socio-economically diverse neighborhood, West Codman Square, Youth Hub's primary neighborhood of focus, is over 90\% Black and/or Latino/a, and is characterized by higher than average rates of poverty, unemployment, and crime, and lower educational attainment, as compared to the City of Boston. Most youth residing in this neighborhood have been affected in some way directly or indirectly by local conditions, including violence, resulting in varying degrees of trauma. Many residents feel as though the community is stuck in generational cycles of poverty, substance abuse, and violence.

In 2010, a collaborative of local organizations in Codman Square (called Millenium Ten), funded by Local Initiatives Support Corporation (LISC), initiated a community-wide planning process to address the neighborhood's many challenges. Dozens of organizations and businesses came alongside hundreds of residents to identify challenges and develop a community contract, including key strategies for community improvement over the next 10 years. One group of participants chose to focus on youth issues, engaging young people and organizational leaders over the course of several months in 2012 to develop an action plan for improving local youth outcomes. The key issues that emerged as needing the most attention included youth violence, educational

\footnotetext{
${ }^{1}$ We have left this article in present tense as written at the time by its authors though Youth Hub had to end
} its formal operations in 2017 due to lack of funding. 
attainment, and employment; and the strategies for change centered around the formation of a "youth hub" - a collaborative initiative to increase opportunity and neighborhood capacity for improved youth outcomes.
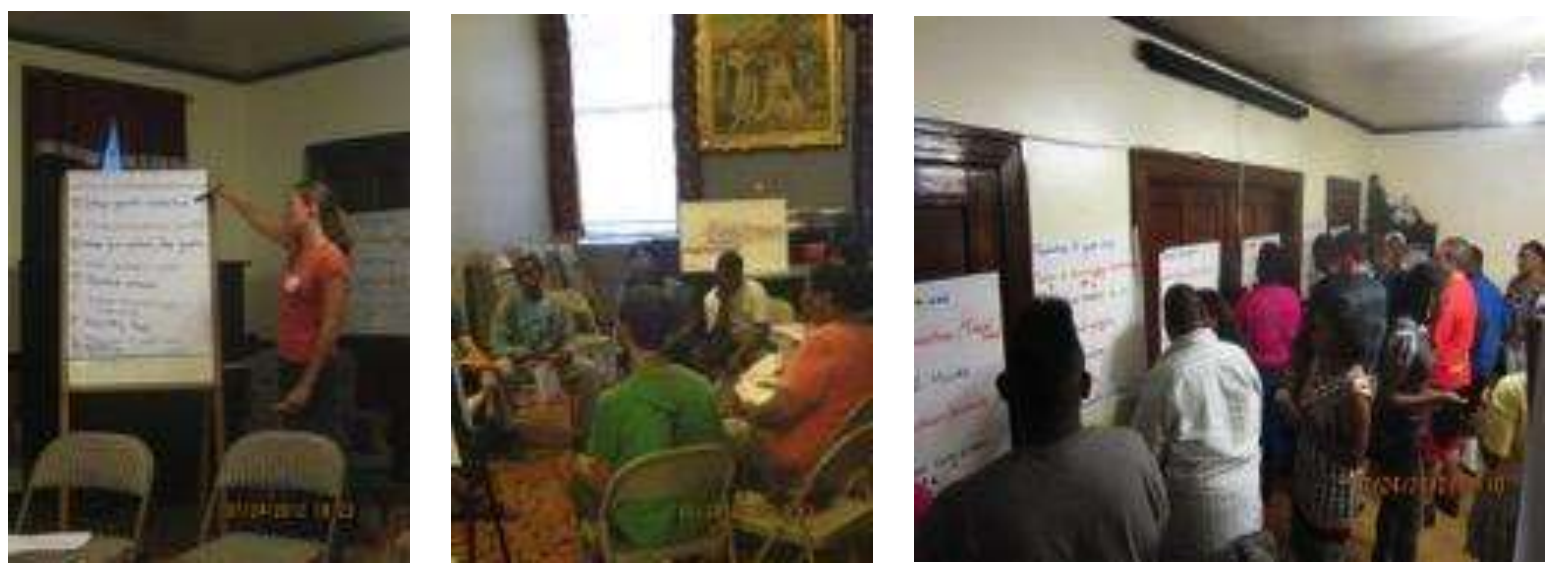

Figures 1-3. Photos from Millenium 10 of youth and adults discussing youth-related issues of concern in Codman Square.

In the following year (2013-2014), a group of six resident youth and six organizational leaders formed a steering committee to guide the formation of the initiative. The group chose to focus first on outcomes related to youth employment, given its priority in the planning process, emerging research affirming the benefits of employment for low-income and youth of color, and recent studies drawing attention to low employment rates for the same population. These studies show that youth employment has benefits that are both immediate and long term, including reductions in youth crime, violence, smoking, drug use, social alienation, and self-harm (including suicide), as well as other anti-social and risky behaviors (Mitchell, Betts \& Epling, 2002). Research also shows that youth employment can lead to higher educational attainment, increased preparedness for adulthood, and overall higher lifetime earnings (Graham, 2014). Despite this abundant research, youth unemployment rates in Massachusetts have doubled in the past decadereflective of a national youth employment crisis (MassBudget, 2012). Further, this opportunity crisis is not experienced equitably. Youth of color from low-income families have the lowest employment rates nationally. In the summer of 2013 in Massachusetts, only $9 \%$ of black male teens from families in the lowest income group had jobs. This was compared to almost $50 \%$ of all white male teens from families earning between $\$ 100,000$ and $\$ 149,000$. Low-income teens and those who struggle with school benefit most from working, and yet they are the least likely to have jobs (Grahman, 2014). The steering committee sought to identify an approach to addressing this need at the neighborhood level. 


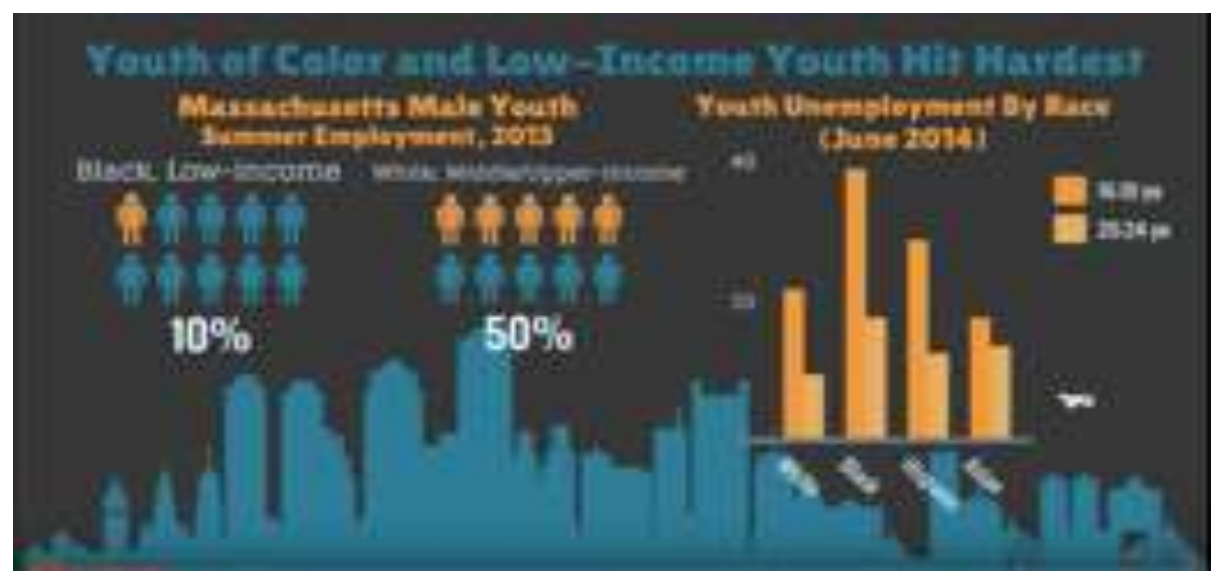

Figure 4. Youth Hub Analysis of Unemployment

The steering committee, composed of youth and adults and collectively representing over 125 years of youth work experience, met consistently over the course of several months to more deeply unpack the issue of youth employment - sharing stories from their own experiences working with youth and the community, as well as discussing related research. Together the group synthesized their collective knowledge and understanding of best practices to develop a shared logic model of youth employment, contextualized for the Codman Square neighborhood. While a typical logic model serves as a road map for a specific program, this shared logic model defined desired outcomes for the neighborhood as a whole (such as increased youth employment rates, and improved connection between youth and local employers), identified factors that influence achieving outcomes (including youth employability and employer readiness), and included possible interventions across organizations and programs in the community (such as subsidized job programs, mentoring, and career counseling). This process was critical not only for better understanding the broader issue and desired outcomes, but also for developing trust and collaboration amongst local stakeholders. Each person and organization involved was able to identify where their work fit in the broader context, while the group as a whole recognized where gaps in resources existed.

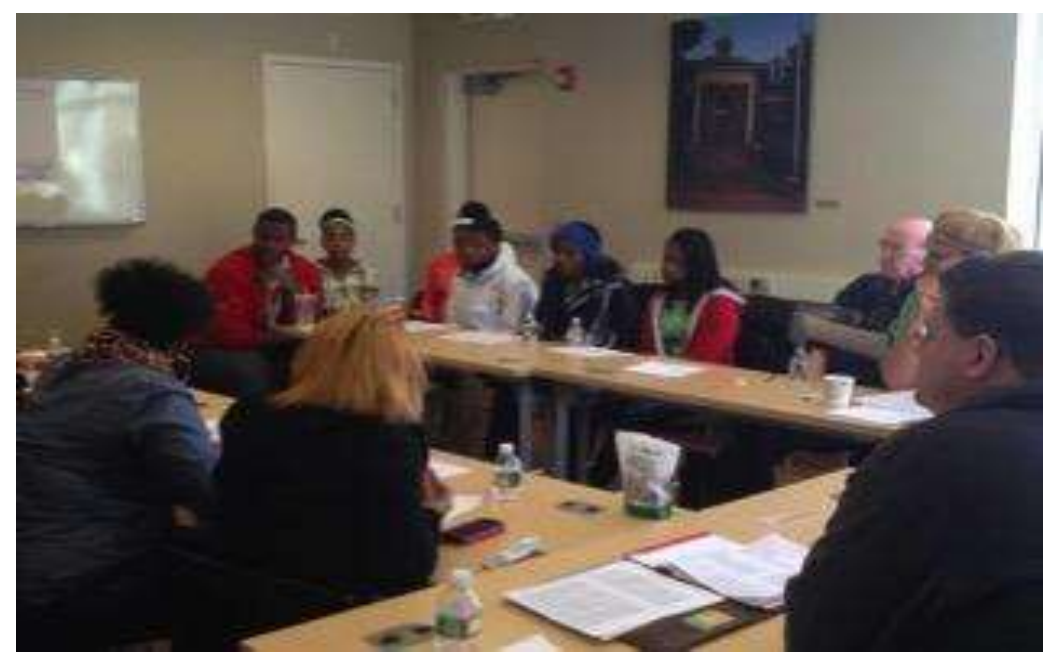

Figure 5. The steering committee discussing the early logic model 


\section{Youth Employment Measurement Model (work in progress)}

The Youth HUB neighborhood coalition began by building a youth employment logic model as a basis for determining what data to collect and how to interpret it

\section{Model}

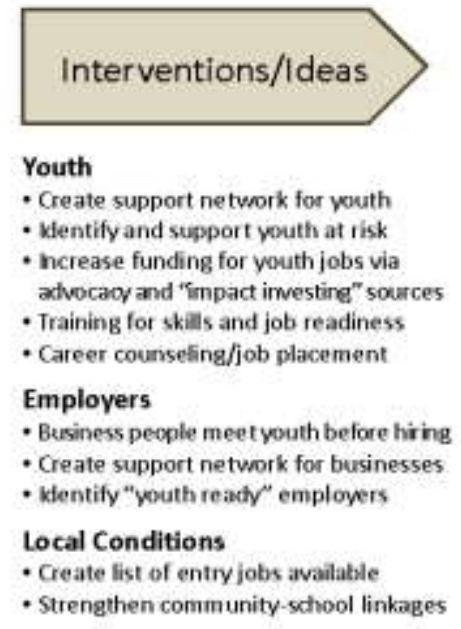

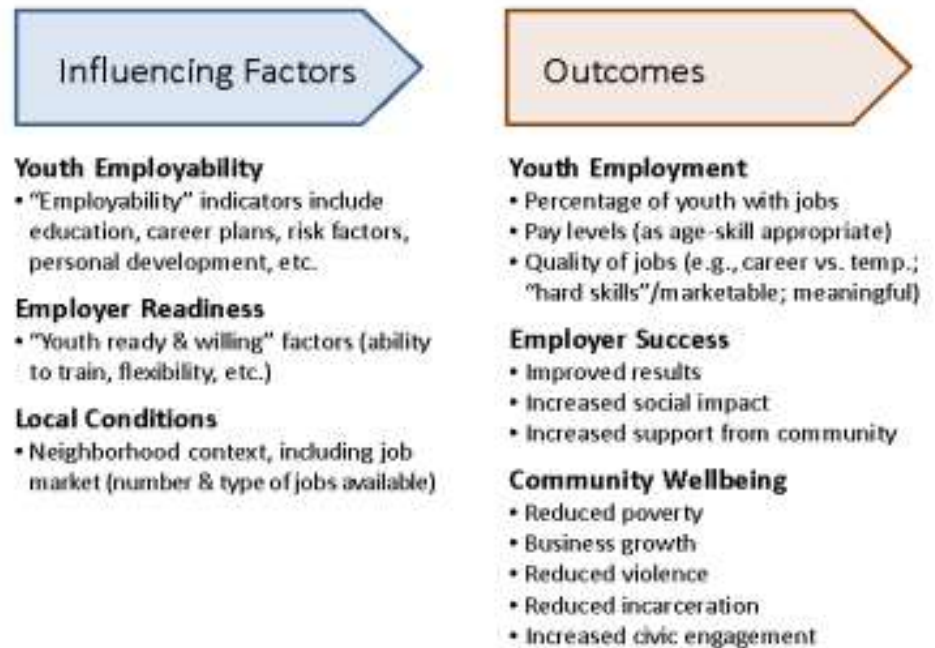

Figure 6. The youth employment logic model

After developing a shared logic model, the steering committee determined that to achieve improved outcomes across the neighborhood, a collaborative and measurement-based approach was needed. Thus, Youth Hub was launched in 2014, to develop an approach that would identify the barriers contributing to low youth employment rates locally, set and measure neighborhood goals related to youth employment, and help facilitate local collaboration and innovation toward improved results.

A smaller "management team," including a part-time paid Coordinator, formed from the steering committee to help develop the new approach and oversee its implementation. The team began by identifying indicators from the logic model and matching them with available public data. It quickly became evident that such public data at the local level was extremely limited. If measures were to be a key component, Youth Hub would have to include data collection as an integrated piece of its newly forming model. The team solicited help from Millennium Ten's evaluation partner, The Center for Social Policy (CSP) at University of Massachusetts Boston, to design this piece of the initiative. Together, Youth Hub and CSP designed a pilot project to collect baseline data in Codman Square related to youth employment, using participatory action research (PAR).

\section{Participatory Action Research (PAR): Benefits and Challenges}

Although Youth Hub did not set out to do participatory action research from the start, PAR emerged early on as a useful tool for data collection and measurement. PAR aligned well with Youth Hub's values of youth leadership and action. With coaching and technical assistance from CSP, Youth Hub launched its first PAR project in July 2014 to begin identifying and addressing local 
barriers to youth employment.

Developing the research model and methods. Youth Hub launched its first PAR project with two part-time adult staff and a team of five local youth, aged 15-17, with each representing one of the organizations on the original steering committee. The team started by collecting qualitative data through interviews of experts, including the Director of the Youth Jobs Coalition, the Director of the local office for Action for Boston Community Development (ABCD), and a local elder with decades of experience running youth programs. These interviews helped provide context for the issue and to build a framework of knowledge for the youth team to use in designing the bulk of their research.

Meanwhile, Youth Hub's Coordinator worked with researchers from CSP to develop an initial survey draft, using indicators identified from the logic model to frame questions. Given the short amount of time available for the project (summer employment for youth is typically 6-8 weeks in July and August), adult staff created the first draft of the survey and then presented it to the youth for feedback, as opposed to facilitating a much longer process of survey creation with the youth team. However, what was intended to be a short feedback session with the youth team turned into several days of the youth critiquing questions and offering alternative words and phrases to make it more understandable and comfortable for youth to receive it. For example, the youth team cautioned against asking income related questions, as the youth recipients were unlikely to know their family income, making the results inaccurate. And questions should be rephrased from "to what extent, if any..." to simply, "how much." They also flagged questions that youth were likely to lie about - such as average grade in school - and suggested replacing open -ended questions with multiple choice ones to encourage a higher response rate and more accurate answers. With this valuable feedback and insight, it became obvious that youth involvement in the development of the research instruments was critical.

After finalizing the survey instrument, it was uploaded to the electronic platform, called Survey Analytics. This particular platform was chosen for its easy-to-use survey generator with many question types, its analysis and visualization tools, and most importantly its iPad application - Survey Swipe - which enabled the youth to administer surveys on iPads without access to the Internet. The iPad application was critical for a few reasons: 1) youth are familiar with and comfortable with technology, suggesting they may be more likely to complete the survey in this format; 2) it was quicker, more efficient, and safer (less chance of losing data) than long paper surveys; and 3) it automatically uploaded and aggregated data so the team could spend their limited time conducting surveys out in the community as opposed to entering data.

Surveying in the community. The youth team then prepared for surveying their peers out in the community. They helped create and then reviewed a behavioral protocol, including standards of professionalism and safety precautions and practices. The youth practiced conducting the survey with one another on iPads to perfect their delivery and improve efficiency. The youth researchers aimed for high efficiency - memorizing questions and anticipating problem areas - with the goal of reducing survey completion time from 15 to 7 minutes - the time they said they could hold the attention of their peers. Additionally, youth researchers reviewed different situations they may encounter and used role-playing to determine appropriate responses. Situations ranged from, "a respondent won't stop rambling and you need to redirect them to the survey," to "someone insists you come into their house to take the survey, but you need to stay in eyesight of your adult supervisor." Through this process, youth learned how to professionally and effectively communicate and problem solve to reach the survey completion goals. Finally, the team set out to pilot the survey with youth in the community. 
Youth Hub collected surveys using a door-to-door approach, where the youth research team canvassed every household to determine where youth of age (initially 15-24, later expanded to 14-24) lived, and attempted to give each youth within the household several chances to complete a survey. Youth Hub chose to first focus on a specific sub-neighborhood of Codman Square, with a total population of about 2,000. This particular sub-neighborhood is known for its rich community involvement and high social capital, which the team hoped would contribute to higher trust and a greater response rate. The survey team used a spreadsheet to keep track of which households were approached and when, how many youth of age lived there, what the response was, and how many surveys were completed. This helped the team identify which houses they needed to return to and which houses were completed. The youth were accompanied in the community by an adult supervisor at all times and conducted surveys in pairs for added safety.

The team set a goal to collect 100 surveys from youth aged 15-19 and 50 surveys from youth aged 20-24. Five-dollar gift cards were provided as incentives to complete the survey. The preparation and training with the first youth survey team took about four of the total seven weeks that the youth were employed for the summer. The team collected surveys for the remaining three weeks and successfully completed about 25 surveys. At the end of their summer employment stint, the team did another round of feedback on the survey after having administered it several times. The Coordinator used this feedback to further improve the initial survey for broader implementation.

Because the initial goal was not yet met, Youth Hub partnered with two local youth organizations - BOLD Teens and The Boston Project Ministries - to help complete the remaining 125 surveys. An additional seven youth (age 16-21) were trained on the updated survey and behavior protocol, with the assistance of three returning youth researchers from the summer survey team. The new research team of ten youth worked 8-10 hours per week after school and on weekends for five weeks, reaching their goal of 150 total surveys in mid-November.

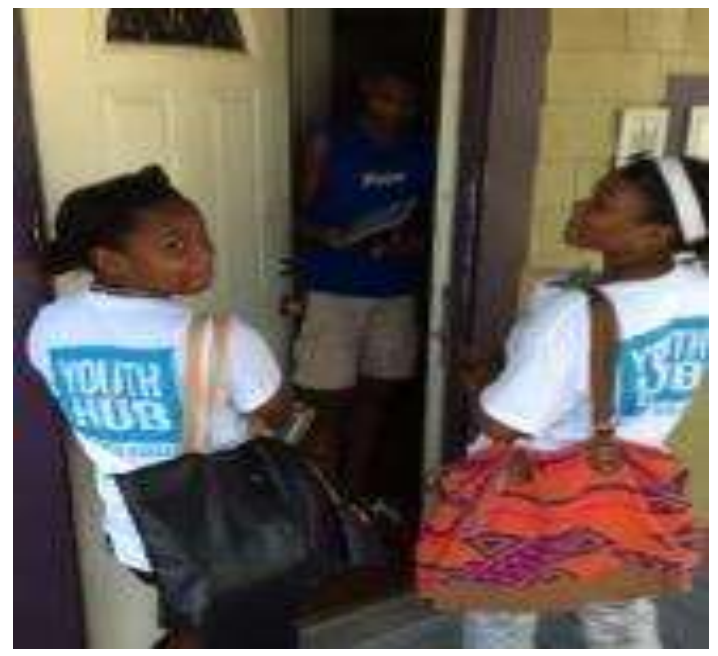

Figure 7. Youth surveyors collecting surveys 


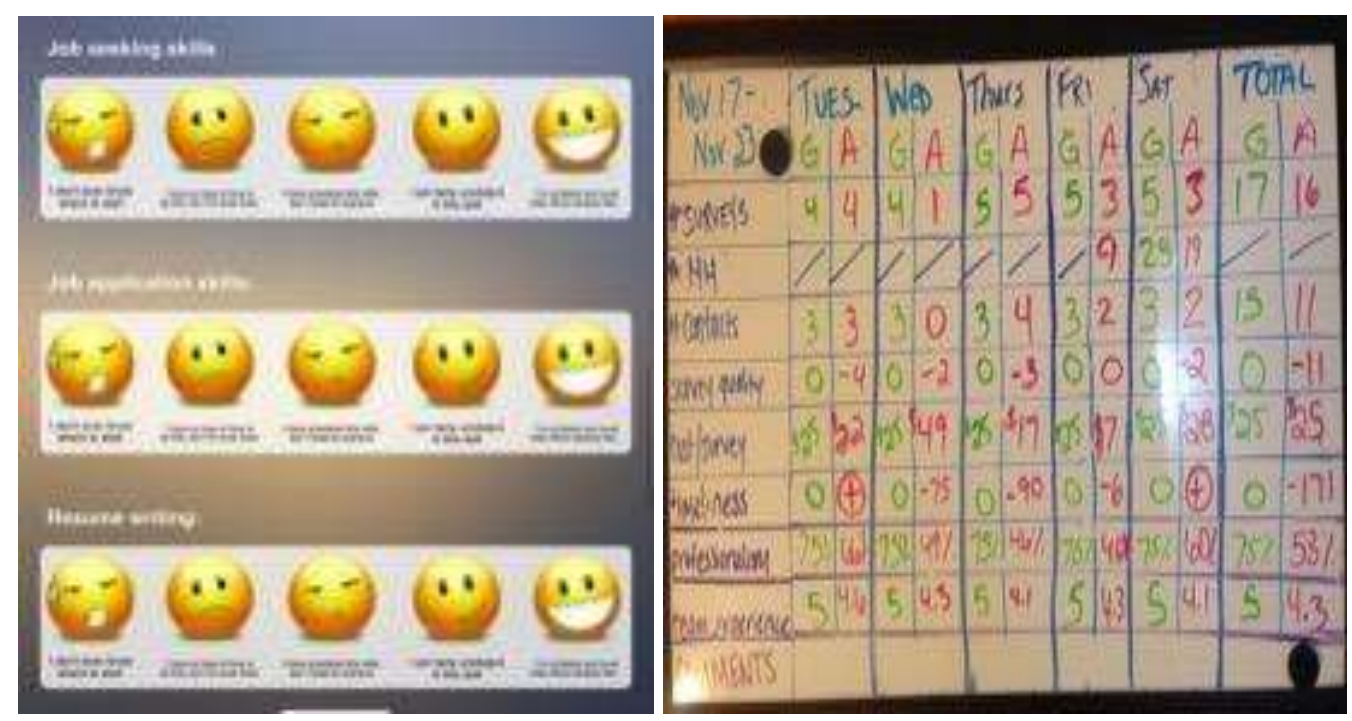

Figure 8. One of the questions on the employment survey (left); Measurement tools used by youth to track progress (right)

Participatory analysis, action, and intervention. In January 2015, Youth Hub used the data from the 150 surveys to begin facilitating participatory analysis processes with youth and partner organizations. Youth Hub invited BOLD Teens and The Boston Project Ministries to bring together youth from their organizations, including those who participated in surveying, to review the survey findings. A total of about 20 youth gathered for a series of meetings to look at the data together and provide critical analysis. They discussed what surprised them, what needed more clarity, and what stood out the most. Youth Hub used human-centered design methods to facilitate a process for the youth to use data in small groups to identify key barriers and develop ideas for improving results. Youth Hub called this process of analysis and problem solving, "innovation circles." In the first innovation circles, youth chose to focus on 1) access to employment programs and opportunities, and 2) job-readiness skills. From the innovation circles, the groups decided on a few key interventions to improve employment results: 1) host a local job fair to bring employment resources to the community, 2) promote employment programs (such as programs that place youth in subsidized jobs for the summer) prior to application deadlines and provide assistance in completing applications, and 3) provide job-readiness training and coaching. 


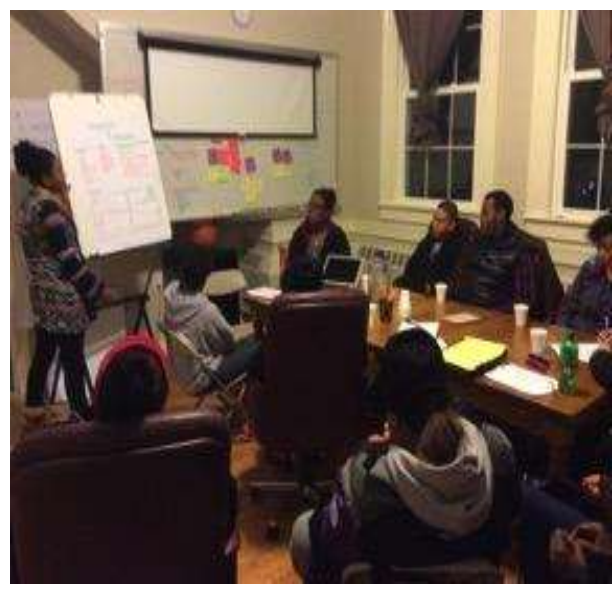

Figure 9. Youth discussing data and developing solutions

Youth Hub, BOLD Teens, and Boston Project Ministries worked together over the course of the next several months to implement these change strategies, including the first ever youth job fair in Codman Square. The youth used survey data to help determine which employers to invite to the fair and which resources to offer - such as skill building workshops on resumes, professionalism, job applications, and interviewing. The group also determined it was important to provide opportunities for youth to fill out applications for subsidized summer employment as well. They successfully recruited 13 employers and had over 100 youth and parents attend.
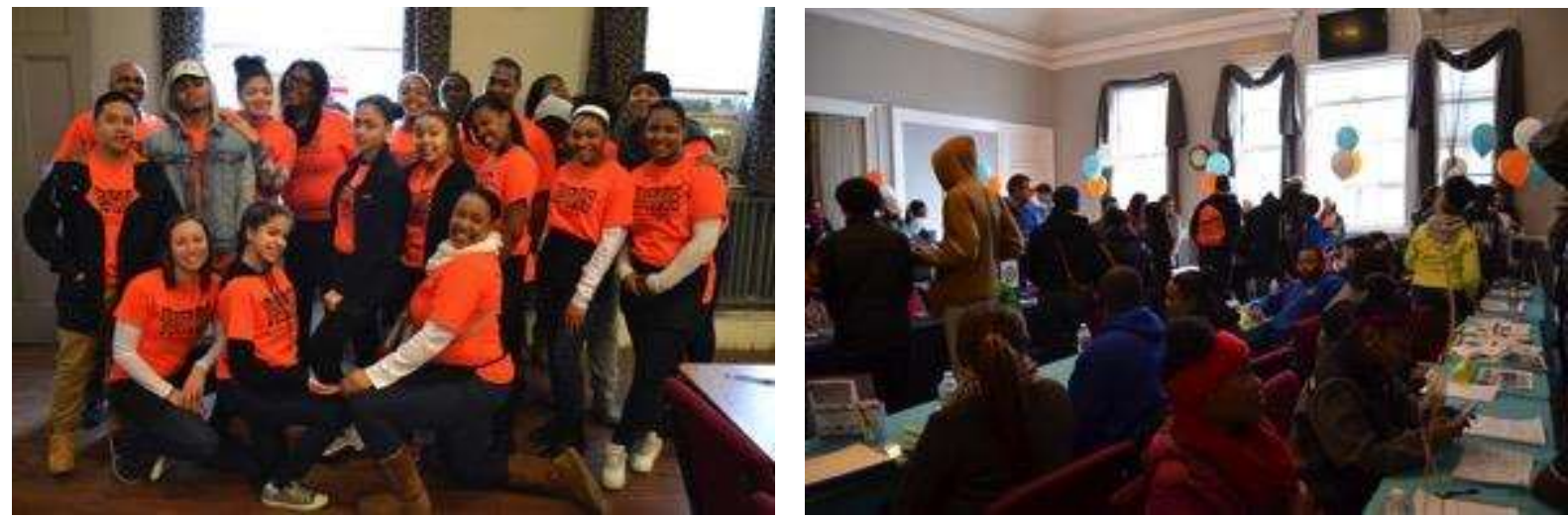

Figures 10, 11. Youth from Youth Hub and partner organizations at the 2015 job fair (left); 2016 job fair (right)

Youth Hub invited other youth organizations and members of the original steering committee to review and respond to the survey data, including ways they could contribute to addressing barriers and improving results. This was particularly important for those organizations that had a limited reach in the neighborhood according to the survey results. As a result of this process, two organizations partnered with Youth Hub to extend their reach and improve youth access to their programs. In one case, Youth Hub collaborated with ABCD to provide application assistance for their summer employment program. In the second, Youth Hub conducted a joint outreach effort with Year Up to canvas particular households with eligible youth to promote their program. The number of applicants to Year Up from the target neighborhood in Codman Square increased from just one reported in the survey, to five, as a direct result of this outreach. 
Youth Hub also used the survey data to craft a proposal for a job-readiness focused program to address several of the key barriers to youth employability. Youth Hub received funding to pilot the Youth Cohort program - focusing on skill building, career exploration, self-exploration, and social support building to improve employability - in spring and summer of 2015. This funding, along with some additional small grants, graduated Youth Hub from a pilot initiative to a small organization (under 501c3 fiscal sponsorship of Third Sector New England), with a full-time Executive Director (former Coordinator) and a full-time Youth Engagement Coordinator.
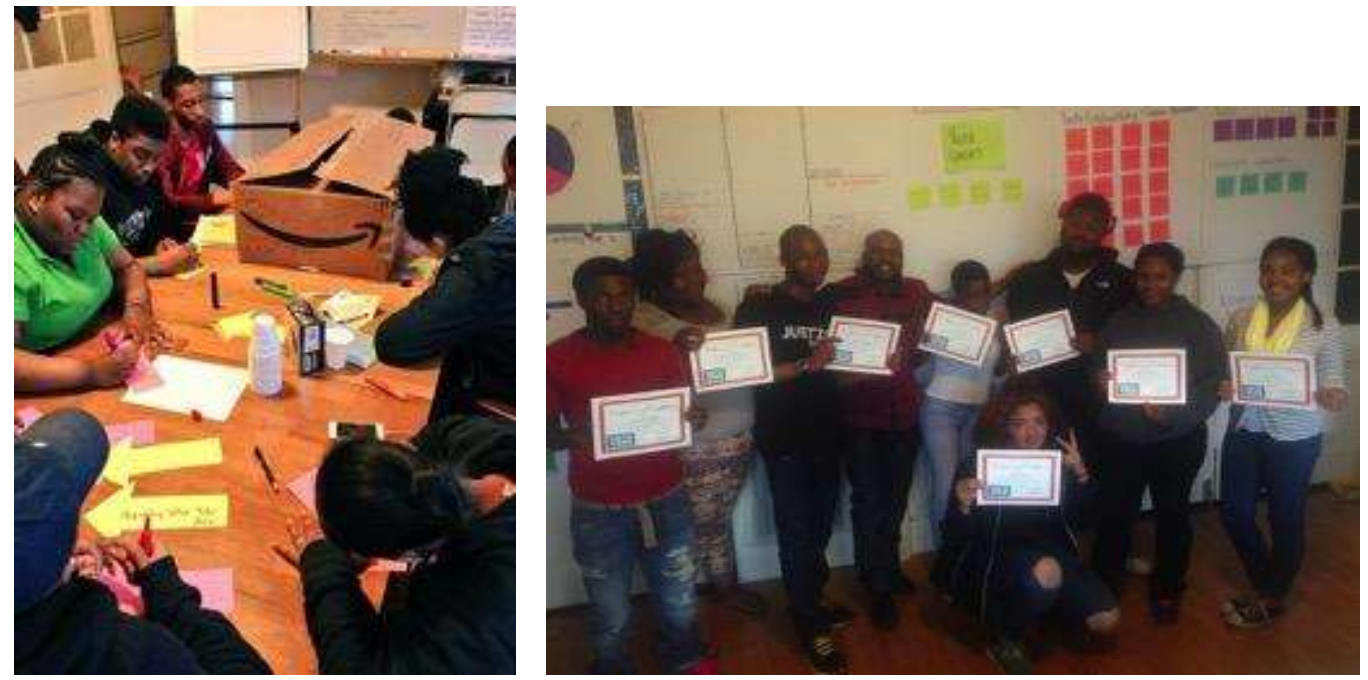

Figures 12, 13. Participants in the 2015 Youth Cohort program doing an activity about selfexploration (left); Graduates of the first Youth Cohort (right)

Iterative process. While PAR typically involves a single cycle of research producing one or more "actions," Youth Hub chose to continue using PAR in an iterative process to go deeper in understanding the youth employment issue and in identifying solutions to improve results. In Summer 2015, Youth Hub trained another group of five (three new and two returning) youth surveyors and expanded the geographic focus to nearly double the total target population. Youth Hub used youth feedback from the previous project to simplify and improve the original survey. This team was much more efficient and completed 166 door-to-door surveys in just six weeks. Fivedollar gift cards were used again as incentives to complete the survey. In addition to completing surveys, the team also promoted a "Youth Hub Membership" where youth could share their contact information to stay informed of opportunities and resources. One hundred percent of survey respondents elected to become a "member" and shared their contact information.

In reviewing these survey results, Youth Hub determined that additional qualitative research was needed to better understand some of the patterns emerging from the surveys. In Fall 2015, Youth Hub hired six youth to form a Youth Leadership Coalition (YLC). With continued technical assistance from CSP, the YLC was trained and supported to facilitate a series of focus groups to gather additional qualitative data from their peers. They completed eight focus groups, with a total of 32 local youth in January, February, and March of 2016. The YLC transcribed and coded transcripts from the focus groups, highlighted key patterns, created data visuals, and formed recommendations based upon their findings. Recommendations included: 1) help youth expand their professional social networks through mentorship based on interest and possible career path; 2) improve subsidized job placement programs by expanding the variety of jobs available, providing opportunities for advancement beyond entry-level/minimum-wage positions based on age, 
experience, and demonstrated leadership; 3) standardize hard and soft skills to promote intentional learning in youth jobs; and 4) provide personal finance education opportunities to youth and families.

In Summer 2016, Youth Hub further expanded its research capabilities with a team of seven youth researchers (four new and three returning). Youth researchers worked with a professor from Boston College School of Social Work to conduct a photomapping project, designing neighborhood tours and using photography to identify assets and challenges in the community. Youth Hub also contracted with Codman Square Health Center to complete a youth-led research project on knowledge and perceptions of youth on matters of sexual health, with the goal of providing recommendations to the health center for improving their sexual health services. This partnership distinguishing Youth Hub's value in the research market - marked an important milestone for Youth Hub's developing model.

In addition to collecting surveys and diversifying data collection methods with focus groups and photomapping, Youth Hub has also continued to expand successful interventions from 2014. The second annual Codman Square Youth Jobs Fair brought in 25 employers and over 350 youth. Youth Hub also planned to improve employability for 50 youth in 2016 through the Youth Cohorts program. Additionally, Youth Hub is cultivating partnerships with technology experts to design and pilot a smartphone application to improve youth access to jobs and resources and is developing a plan for engaging local employers to improve their readiness to employ youth successfully.
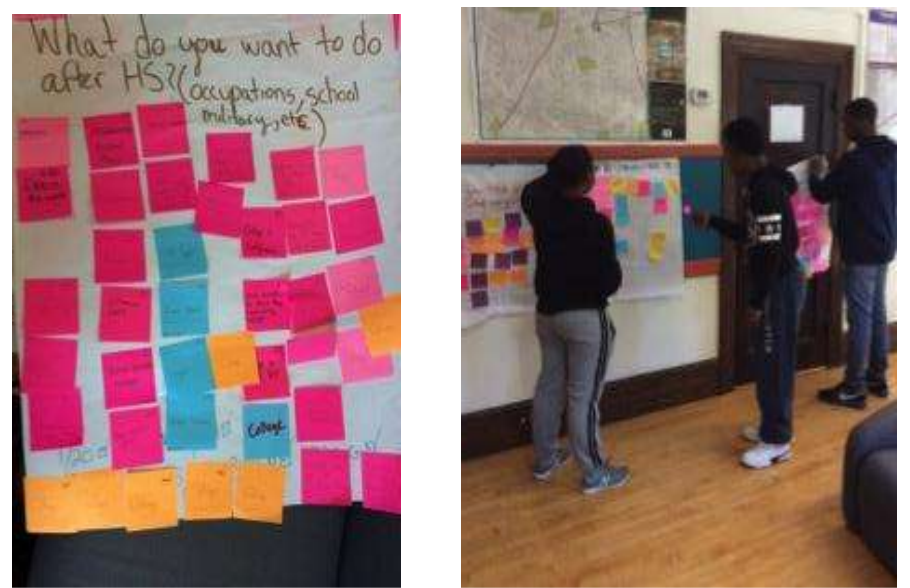

Figures 14, 15. Sample code sheet from focus groups (left); Youth coding data from focus groups (right)

Key survey results. In 2014 and 2015, Youth Hub collected a total of 312 surveys about employment amongst youth aged 14-24 living in the West Codman Square neighborhood, representing over $20 \%$ of the total youth population in the geographic area of focus.

Demographically, survey respondents accurately reflect the broader community, with about $76 \%$ Black or African American, 21\% Latino or Hispanic, and about 3\% White (Youth Hub, 2014).

Youth Hub's survey results indicate that youth have low rates of engagement in employment and related activities. The 2015 survey revealed that $90 \%$ of youth expressed a need or desire to work; and 91\% stated that, when employed they use a portion of their paycheck to help support their family. However, on average, only $25 \%$ of youth are employed during any given month (Youth Hub, 2015). This is less than half the employment rate amongst youth from middle to upper-income families in Massachusetts (MassBudget, 2012). Although employment rates are higher during July and August, still only $48 \%$ of youth had a job or internship in the summer of 2015. In terms of job 
and career exposure, only 25\% indicated they had ever shadowed an adult at their job, and only 53\% had an internship or steady volunteer experience. According to the 2014 survey, $19 \%$ of youth aged 14-24 were disengaged - neither working nor in school.
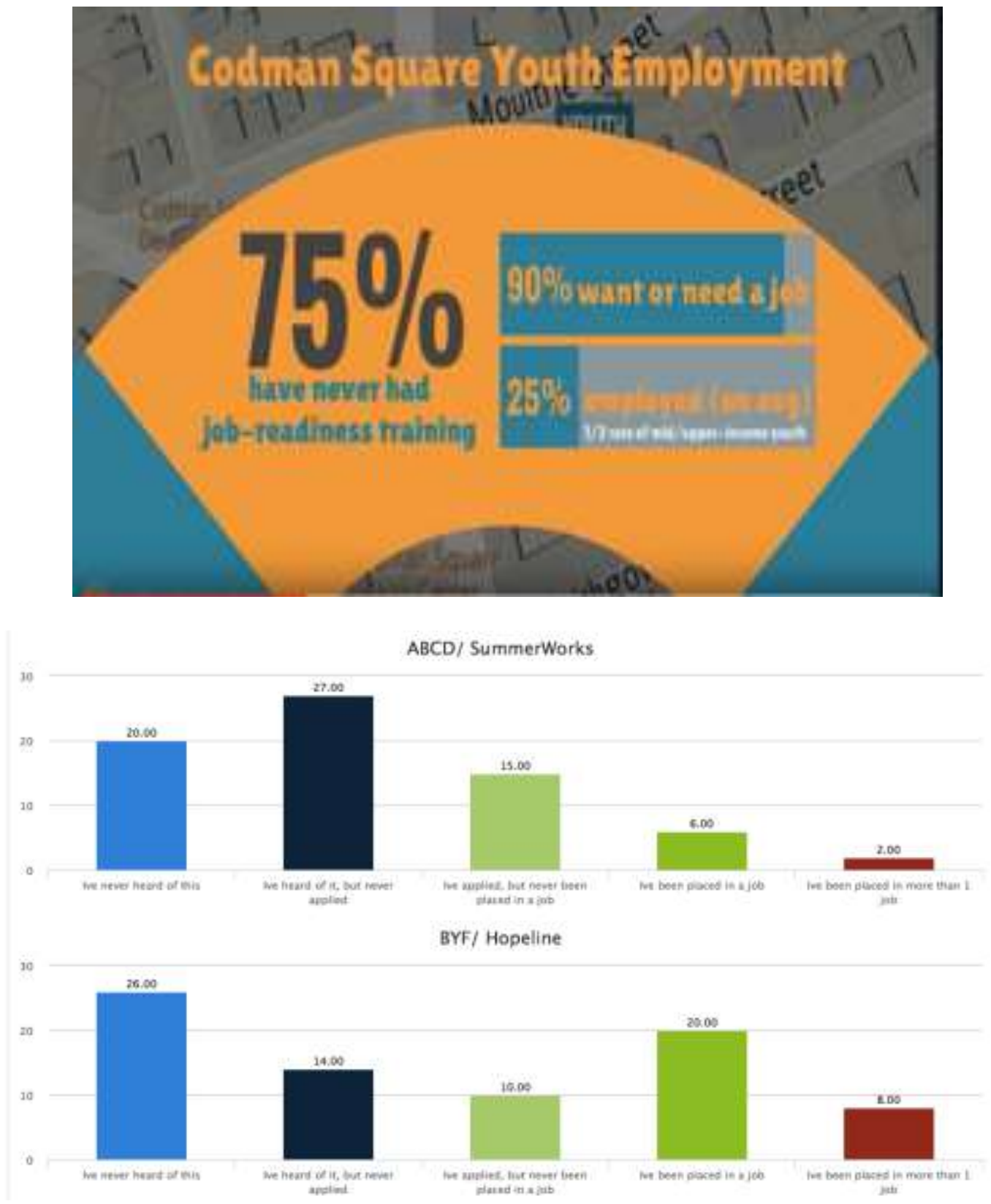

Figure 16, 17. Some key survey results

The surveys also indicate low access to job placement and job-readiness focused organizations. The survey asked youth about the city's most prominent job-placement programs such as, Department of Youth Engagement and Employment (DYEE), Action for Boston Community Development (ABCD), Youth Opportunities Unlimited, Year Up, Private Industry Council, and more. Although DYEE and ABCD had the highest application rates, 35\% and 37\% 
respectively, the other organizations' application rates ranged from only $8 \%$ to $16 \%$.

Similarly, the surveys highlighted a gap in access to employment and career-readiness supports and trainings. The 2015 survey indicated that only $41 \%$ of youth had ever been engaged in any kind of job-readiness training or workshop. A total of $92 \%$ of youth (2014) indicated that they needed more support in order to attain their future employment, education, and career goals. Most frequently identified areas for additional support included family support, college and career counseling, job skills workshops, and internships.

Youth Hub's work is distinguished by its capacity to combine quantitative, qualitative, and action-generated data to test assumptions about what interventions will work, under what conditions, and for which youth (considering demographic, educational, developmental and other characteristics). Most of this data is not available through public or institutional sources and can only be created and collected by youth who share a high level of trust and commitment to shared goals. Youth Hub's social network - its community of youth-is an essential and distinctive foundation for PAR that can generate breakthrough results.

\section{Benefits}

PAR has many unique benefits that other methods of research do not. PAR provides a deeper contextual understanding of the problem, helps ensure that recommendations are relevant and realistic, promotes greater participation in the research and in solutions when implemented, and elevates the voices of the community.

PAR helps ensure that problems are framed within the context in which they are experienced and from the perspective of those most aggrieved by them. The researchers are experts in the issue at hand because they are living it. This provides the opportunity for the development of more effective research tools (i.e. surveys) and deeper contextual analysis of data. For example, Youth Hub knew how to ask survey questions in a way that youth would understand and would feel comfortable answering. Also, youth researchers were able to provide explanations from their own experiences as to why certain patterns were emerging - like the times of year youth were more likely to be employed. Likewise, when recommendations for improving outcomes come from those whom solutions would impact, in this case youth, they are more likely to appropriately address the needs, so time and resources are not wasted on solutions that would be dismissed immediately. For example, Youth Hub could have begun developing a website to help youth access jobs and resources; but instead, given the experience of youth researchers, they immediately started with a smartphone application because youth are more likely to access the internet via their smartphone rather than a computer. Additionally, the leadership of the youth researchers was pivotal to the high survey response rates and successful implementation of the job fair. Youth were far more likely to engage in a survey with a peer whom they could identify with and feel comfortable with; and youth leaders knew exactly the right ways to promote the job fair to get a successful turnout. Within this context, PAR contributes a great deal to framing action-research questions that will identify ripe opportunities and inform practical efforts for improving results and creating systems change.

While participation of youth was key in Youth Hub's research, having the support of skilled research partners associated with a recognized university, helped the legitimacy of Youth Hub's research in both the eyes of residents and institutions. This recognition opens up access to issuespecific knowledge for researchers and the community - in Youth Hub's case, the issue of youth employment - combined with the added element of youth development and employment experience that Youth Hub's staff brings to the table to shed light on the meaning and impact of the data that PAR yields. This community and academic partnership has also opened up many doors for Youth Hub to share its work beyond the immediate community. For example, Youth Hub has presented its 
work to researchers and community activists from across the country at a conference hosted by URBAN at the University of Massachusetts Boston.

Youth Hub has experienced the benefits of PAR even beyond the research itself. PAR has become an integral piece of the Youth Hub model of civic engagement, outreach, and youth leadership development. In collecting surveys in the neighborhood, youth researchers come to better know their own community, while also connecting with hundreds of community members they otherwise likely would have never known. One of the youth researchers described an experience she had walking home one day and being greeted by several neighbors she had spoken to while surveying. She was struck by their friendly attitude toward her, as she typically wouldn't expect to be greeted by strangers. When the community responds positively to Youth Hub's efforts, youth researchers have the opportunity to experience their community differently - for its assets, as opposed to its liabilities. In this process, Youth Hub has found that youth develop greater passion for seeing improvement and contributing to the betterment of their community.

Similarly, with a door-to-door survey approach, Youth Hub has been able to identify and engage youth who are otherwise disconnected. Going to youth is a different outreach model than the one employed by most other local organizations that distribute information and then depend on youth to come to them. Surveying provides organic opportunities to connect youth with resources on the spot. In several instances, survey respondents inquired about programs and organizations mentioned in survey questions, and the survey team was able to provide them with additional information. In another situation, the manager of a local Walgreens recognized the survey team by their Youth Hub t-shirts and stopped them to inform them that he was hiring. That same day, the survey team was able to direct a young woman to the Walgreens manager to begin the application process.

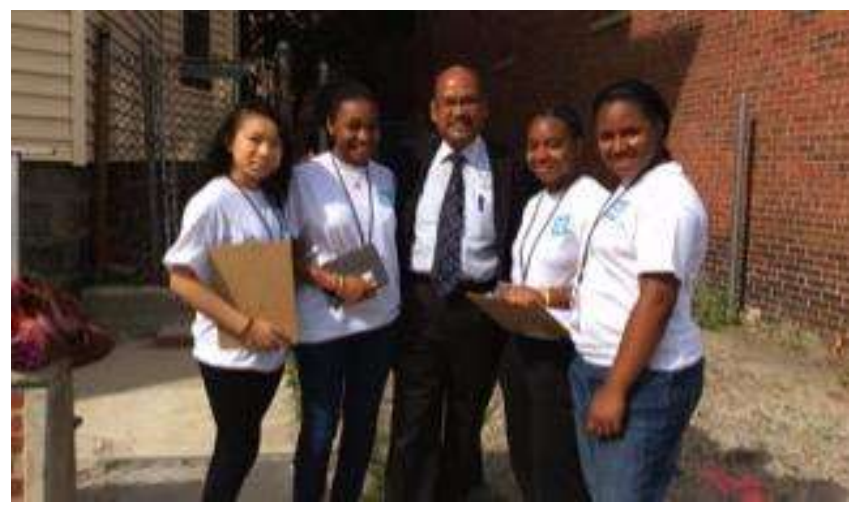

Figure 17. Youth surveyors posing with former City Councilor, Charles Yancey.

Engagement in PAR has been an excellent way of building leadership skills amongst the youth researchers. Youth researchers learn how to take ownership of goals (for example, the number of surveys they need to complete), and to work together as a team to strategize for meeting these goals. In consistently reviewing goals and outcomes, youth learn how to take responsibility for shortcomings, hold one another accountable, and problem solve to improve performance. For example, one survey team realized that their most efficient time for surveying was between the hours 4:00pm and 6:00pm, so opted to boost their efforts during those hours and use their time earlier in the day to engage youth on social media or via phone and email. Youth researchers have also had several opportunities to speak publicly about their participation in PAR and about their research findings. 

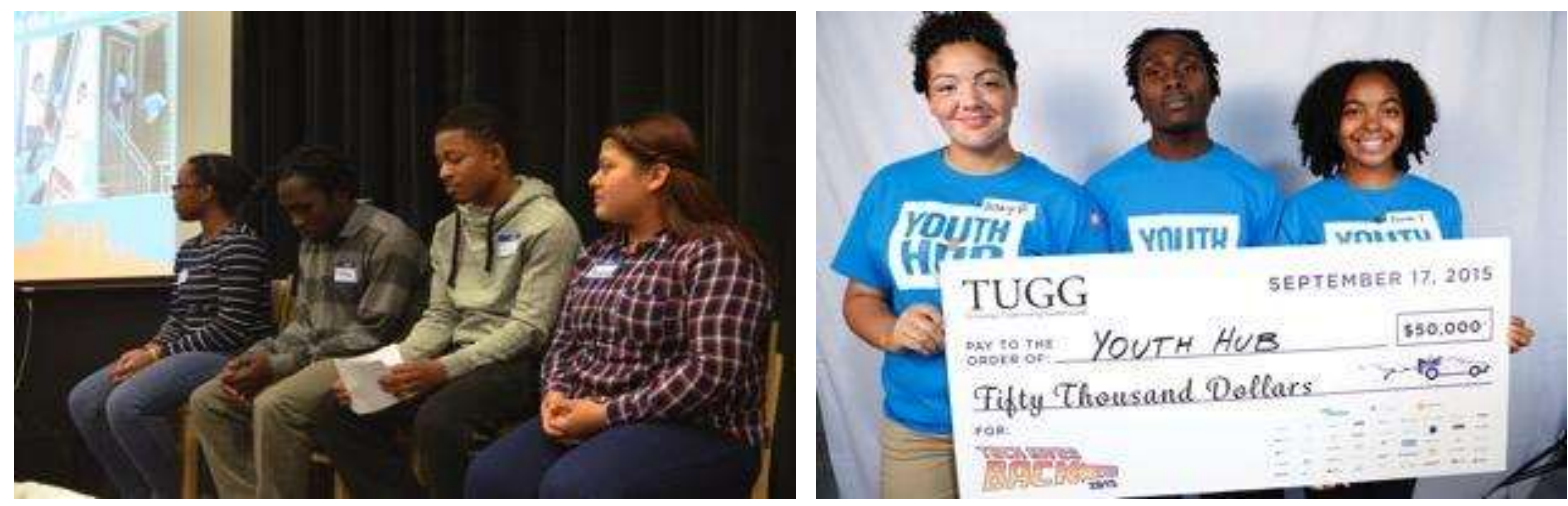

Figures 18, 19. Members of the Youth Leadership Coalition speaking at an event hosted by URBAN

Boston (left); Youth Hub alumni displaying an award they helped win at a local fundraising event (right)

\section{Addressing Issues of Systemic Racism through PAR}

Seeking to bring about social change in a community such as Codman Square, where over $90 \%$ of residents are Black and/or Latino/a, necessitates a thoughtful consideration of the effects of systemic racism in every aspect of work - including the research process. While some may argue that traditional research in communities of color - led by academic researchers, often White, middleclass, and from outside of the community - perpetuates a paternalistic model of (White) "expert" or "helper" and (Black/Latino/a) "subject" or "client," PAR provides an empowering alternative. PAR provides the opportunity to develop leadership from within - in Youth Hub's case amongst young people of color. It has potential to help flip traditional power structures, equipping "participants" as experts, informants, and influencers. Also, participant researchers are much more capable of interpreting data and suggesting appropriate actions with consideration of race and systemic racism. In researching issues largely influenced by systemic racism - such as youth employment in urban neighborhoods - PAR is a necessary model, not only for quality research, but also to not perpetuate potentially harmful paternalistic models.

\section{Challenges}

Youth Hub utilizes PAR for the purpose of elevating the community voice, promoting youth leadership, and ultimately improving neighborhood incomes. Although Youth Hub receives technical assistance and guidance (including training for youth) from CSP, the research is truly led, conducted, and analyzed by youth. Within this framework, tensions occasionally arise amongst community activists and scholars regarding academic rigor and legitimacy. For example, while professional researches might find digital and scientific analysis tools necessary to determine patterns and relationships in data, it may suffice for Youth Hub to use colored post-it notes and flip chart paper. Also, given the outside demands - including school, family, and other social, emotional, and economic stressors - youth often struggle to give the project the commitment and attention it needs. They also may not realize the value and guiding purpose of their work as researchers and therefore loose connection to the process. In addition, the transient nature of the youth population and seasonal cycles of youth employment, make it nearly impossible for the same group of youth to stick with the project from beginning to end. This hinders ownership of the data and investment in strategies and action to improve results. To combat this instability and to sustain commitment and active youth engagement, adult partners, such as the Youth Hub staff and research partners at CSP, are needed to provide consistency, supporting youth-led efforts throughout each step of research. 


\section{Participatory Action Research and Knowledge-Production}

Within the Youth Hub framework and research model, "knowledge production" is defined and valued quite differently from traditional research. A necessary motivation for Youth Hub's research is to inform action by participants for desired outcomes. Thus, knowledge production is only as valuable as its contribution to effective action and improved results. "Knowledge" is defined not only by concepts and information used to guide the design of an intervention or policy, but also by the practices applied for improved results. Foundational to the theory of change is that breakthrough results can only be achieved by building community capacity for collective actionlearning. Just as conventional research typically focuses on conceptual insights, not action, community change generally focuses on collective action, not generating new problem-solving capabilities required to bridge divides and adapt solutions over time. Youth Hub seeks to combine capabilities for both generating insights and acting on them, using the PAR model.

\section{Benefits}

PAR allows for a rigorous understanding of current conditions (e.g., level of youth employment and factors that affect it, and how); relative efficacy of current intervention which forms the strongest foundation for collective efforts; and ongoing action-learning to improve results. This effort clearly identifies a need as valid, and is supported by legitimate data to promote motivation, collaboration, innovation, and attract funding.

Also, participation in all phases of the research process-including framing problems, defining data requirements, collecting and interpreting data, and using it to guide ongoing actionlearning-enhances legitimacy and usefulness of research and the solutions it yields for community members and institutional partners, and provides a common language to increase mutual trust and respect. It also builds skills and a culture that values data for testing opinions in valid, collaborative ways, providing a context for challenging, supporting, and shaping subjective views and personal experiences, and building evidence that can help confirm or disconfirm assumptions. Lastly, commitment to action research means that when the data cannot provide conclusive evidence, there is a process for continually designing ways to test opinions in action.

\section{Challenges}

Youth Hub often experiences tension in attempting to bridge research and community change models and achieve legitimacy from both. Research institutions push for more academic rigor in knowledge production, not recognizing the value or respecting the often messy process of engaging the community as leaders. Community change institutions (such as foundations), push for quicker action - to "just do something" - rather than valuing the PAR process for improved interventions and sustained results. Both of these sets of pressures can get in the way of committing to and developing an ongoing action-learning and innovation model embedded in the community. Similarly, while Youth Hub seeks to produce population-based change - such as total number of youth employed in Codman Square - by applying multiple solutions for improved results in a neighborhood, community change funders are more interested in understanding direct program outcomes - such as number of youth placed in jobs by Youth Hub. Also, action-research is unfamiliar to most people, particularly funders, and seems unnecessarily difficult, expensive, and time-consuming, when many consider current or available interventions as good enough. This tension makes it difficult for Youth Hub to step outside of providing traditional youth programming to focus on new solutions and neighborhood-wide outcomes, while still satisfying requirements of funders. 
PAR can also challenge those in power (formal and informal, and based on position, resources, status, etc.) because it may contest the design of programs, policies, and other interventions. For example, in Youth Hub's case, the research results challenged the application process of one longstanding youth agency. Youth Hub's research highlighted unnecessary challenges in the application that discourages youth from completing it alone, suggesting that only youth with adequate adult support actually finish the process - not necessary the "highest risk" youth that the agency desires to reach. Issues of criminal justice reform, violence, and access to resources that may come up through this method, also question the distribution of resources and the quality of the resources that are available.

\section{The Youth Voice: Leadership, Ownership, and the Community}

Since its inception, Youth Hub has valued the leadership and agency of local youth. Youth were key in the formation of Youth Hub - including both involvement in M10 and also representation on the initial steering committee, where youth representatives partnered alongside local non-profit, business, and academic leaders to further define the youth employment problem and develop a set of possible solutions. From here, the youth-led structure of Youth Hub emerged, where a team of youth staff is hired each year to engage in PAR projects relevant to youth-issues in the community. These youth teams, known as the Youth Leadership Coalition (YLC), work to define the problem (through engaging peers in PAR), identify possible solutions using participatory methods of innovation, implement solutions (such as a local youth jobs fair), and measure results. Youth become experts on the issues that affect them most and are equipped to inform and influence programs and policies for improved outcomes.

Youth Hub also creates a structure and framework that supports the YLC's ability to manage itself. This begins with a participatory process of creating a contract for team values and expectations, as well as performance goals related to the PAR work to be done, for which youth are expected to hold themselves and one another accountable. Regular feedback/accountability sessions help encourage youth to take responsibility for their own actions as well as to hold others accountable for behavior that is inconsistent with expectations and hinders achievement of goals. For example, in reviewing goals for timeliness, youth may reflect on how lateness affects the team's ability to reach their goal for the number of surveys completed and decide to adopt a practice of texting one another reminders to be on time for work.

\section{Benefits}

For Youth Hub, PAR has emerged as a valuable tool for promoting youth leadership, amplifying youth voice, and promoting youth-led positive social change in the community. Adding agency to their efforts, youth leadership in research and social organizing promotes meaningful involvement and enthusiasm in the process of social change. This process also allows youth to define current youth issues, identify solutions that are important to them, and implement change strategies. This kind of leadership is empowering and transformational for individual youth and the community.

Because youth respond better to other youth, participation in surveys and focus groups is far higher with youth in the lead. Also, other residents respond extremely well to youth researchers out in the community. With their t-shirts, badges, and iPads, they visually represent the assets (as opposed to the liabilities) youth bring to our communities. Youth Hub surveyors have often been stopped and thanked for their efforts to make the community a better place. 
Youth-led PAR also provides opportunities for youth to take increasing responsibility for results and interest in using results to adapt the work process-for example, seeing that cost per survey was much better when team members all showed up to start work on time, and when they scheduled surveys for times of day when peers were most likely to be home. Youth Hub's PAR approach sets goals and tracks progress so youth can assess their work for learning, reinforcing team interdependency/commitments, and celebrating successes. As the research unfolds, youth take pride in their results - for example, achieving the targeted number of surveys by the due date; feeling their influence in conversations with stakeholders such as employment agencies; collaborating with partners such as technologists while co-creating apps to make it possible to scan for job opportunities on a cellphone; influencing employers' attitudes towards youth hires; presenting at conferences with researchers, influencers, and policy-makers; and guiding the development of homegrown interventions, including job fairs, peer cohorts, application-support workshops, and others.
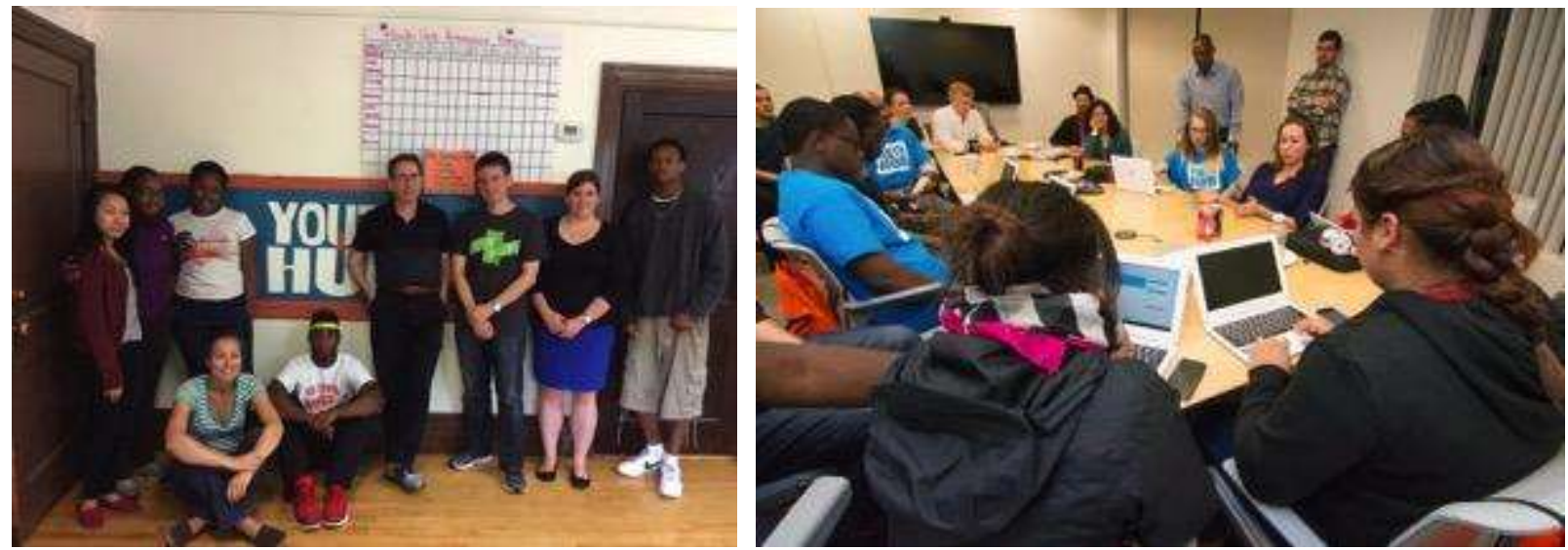

Figures 20, 21. Partners from Code for Boston visiting Youth Hub to get feedback on a job search app prototype (left); YLC discussing Jobcase job search platform with Jobcase staff

\section{Challenges}

Unlike some youth development programs that seek to retain their youth participants for as long as possible, Youth Hub's goal is for youth to advance in their personal career goals, such as obtaining a job, even if it takes them away from their work at Youth Hub. Consequently, Youth Hub expects significant turnover amongst the youth researchers and leaders. Although this turnover indicates that youth are advancing, combined with the transient nature of this age population and the seasonal nature of youth employment cycles, Youth Hub is constantly retraining new youth, as well as putting forth a lot of effort to maintain consistency in culture and values from one group of youth to the next. It is also challenging to get new youth leaders to feel ownership over the work that has been done by previous youth and continue to build on it, rather than backtracking and reinventing. Many of the youth are also facing adversity — at home, school, and community — which affects their attendance and prevents them from being fully present, whether physically or emotionally. For example, 3 of 12 survey team members in 2014 were evicted from their home in the neighborhood and moved to housing in a town an hour away.

Also, youth in the program often need academic help beyond what they receive in school or emotional support beyond what they receive at home. The challenge has been to figure out how to balance giving this extra support with the objectives of the work at hand. Youth in general need extensive and consistent coaching in all phases of the work, and this requires skilled coaching and support, particularly when encouraging high levels of self-management. Youth Hub has to ensure 
that youth have enough skills and team capacity to focus on shared goals and can recognize their limits (e.g., when facing a particularly complex technical or social problem) and remain open and responsive to coaching and guidance when they need it.

Another challenge that Youth Hub has faced occurs when receiving invitations to present about the work. Another challenge that Youth Hub has faced concerns invitations for the youth to present the work. These invitations are often for events scheduled during the standard workday when youth are in school and so are not genuinely conducive for youth participation.

\section{Conclusion}

While Youth Hub began as a small initiative to improve youth outcomes in a local neighborhood, it has emerged as a leader in implementing youth-led participatory action research for leadership development and improved results. Initiatives and organizations across Boston, the United States, and even Canada have sought to learn from Youth Hub's model and experience with youth-led PAR. With continued improvement and expansion of its Youth-Driven Participatory Action Research and Innovation model, what we are now calling YPARI, Youth Hub is striving to develop digital badges to provide recognition for skills youth participants develop related to research, data analysis, organizing, advocacy, team management, communication, and others. With recognition from university partners, such badging would improve pathways to higher education and careers for youth participants, while also further distinguishing Youth Hub as a legitimate research partner for public, non-profit, and private-sector projects. Youth Hub also hopes to expand the model, supporting coalitions of youth across Boston and beyond to use YPARI to develop young leaders and transform communities.

\section{About the Special Issue}

This article is part of a special issue of $\operatorname{EPAA}$, Collaborative Research for Justice and Multi-Issue Movement Building: Challenging Discriminatory Policing, School Closures, and Youth Unemployment that was edited by Ronald David Glass and Mark R. Warren and curated by the Urban Research Based Action Network (URBAN). This special issue reflects the network's commitment to producing and utilizing research for justice that combines rigorous scholarship with the arts to engage both the head and heart so as to deepen and express our social justice values in our scholarship. In addition to the cases highlighted in the title of the special issue, there are also essays that interrogate the limits and possibilities of universities for supporting collaborative research for justice, that explore the role that URBAN has played in fostering the formation of both an academic field as well as experiments in fusing knowledge production with knowledge mobilization and community organizing to build movements for justice, and that argue for multi-modal forms of knowing to build the critical solidarities needed to speak truth to multi-scalar powers at local, national, and global levels. These provocative essays are integrated with graphics that explore themes of how collaborative research for justice is related to advocacy and research rigor, how it must navigate institutional barriers and create institutional supports, and how it can play a powerful role in policy development and change. One graphic on the ethics of collaborative community-based research is also integrated with a video commentary. Additional videos feature scholars and activists sharing key lessons about turning points in their careers, accounts of how they put their research to work for justice, and advice they have for the next generation. Another video features scholar-activists reflecting on their experiences as publicly engaged scholars. Taken together, this special issue provides robust guidance for putting truth seeking to work on behalf of and in partnership with the least advantaged communities. 


\section{References}

Graham, R. (2014, May 2). Are teen jobs becoming a luxury good? The Boston Globe.

MassBudget (2012, Dec 3). Youth and Work in Massachusetts. http://massbudget.org/report_window.php?loc=massbudget_youth_employment.html

Mitchell, D. P., Betts, A., \& Epling, M. (2002). Youth employment, mental health and substance misuse: A challenge to mental health services. Journal of Psychiatric Mental Health Nursing, 9(2), 191-8.

Tandon, S. D., Marshall, B., Templeman, A. J., \& Sonenstein, F. L.(2008). Health access and status of adolescents and young adults using youth employment and training programs in an urban environment. Adolescent Health, 43(1), 30-37. doi: 10.1016/j.jadohealth.2007.12.006.

Youth Hub. (2014). Youth Employment Survey 2014. Boston, MA: Author.

Youth Hub. (2015). Youth Employment Survey 2015. Boston, MA: Author. 


\section{About the Authors}

\section{Rachele Gardner}

rachelej.gardner@gmail.com

Rachele Gardner, founder and former Executive Director at Youth Hub, is now an independent consultant supporting mission-driven organizations to adopt the Youth-Driven Participatory Action Research and Innovation model, implement outcome-driven programming, and develop innovative strategies for community engagement and empowerment.

\section{William M. Snyder}

Civic Stewardship Initiative

William M. Snyder is a principal at the Civic Stewardship Initiative (www.civicstewardship.com), where his work focuses on promoting community-organization collaboration for racial equity at the metro level.

\section{Ayda Zugay}

ROCA

Ayda Zugay is currently working as the Assistant Director of Learning and Evaluation across all sites at ROCA, serving locations from Boston to Baltimore. She is a refugee, passionate about criminal justice and immigration issues, as well as how systemic job reform has the power to rise up people from poverty.

\section{About the Guest Editors}

\section{Ronald David Glass}

University of California, Santa Cruz rglass@ucsc.edu

Ronald David Glass is Professor of Philosophy of Education at the University of California, Santa Cruz, USA, and Director of the Center for Collaborative Research for an Equitable California (CCREC). His recent work focuses on the ethics of research, and the foundations of his philosophy have investigated ideological (trans)formation, education as a practice of freedom, and the role engaged research and public learning processes in struggles for justice.

\section{Mark R. Warren}

University of Massachusetts Boston

Mark.Warren@umb.edu

Mark R. Warren is Professor of Public Policy and Public Affairs at the University of Massachusetts Boston. Mark is the author of several books on community organizing for racial equity and educational justice, including Lift Us Up Don't Push Us Out! Voices from the Front Lines of the Educational Justice Movement. He is a co-founder and co-chair of the Urban Research Based Action Network (URBAN).

Guest Associate Editors: Lindsay Morgia (University of Massachusetts, Boston) and Ben Teresa (Virginia Commonwealth University) 


\title{
SPECIAL ISSUE \\ COLLABORATIVE RESEARCH FOR JUSTICE education policy analysis archives
}

Volume 27 Number $54 \quad$ May 20, $2019 \quad$ ISSN 1068-2341

\begin{abstract}
(c)
SOMIERIGHISRESERVED Readers are free to copy, display, and distribute this article, as long as the work is attributed to the author(s) and Education Policy Analysis Archives, it is distributed for noncommercial purposes only, and no alteration or transformation is made in the work. More details of this Creative Commons license are available at http://creativecommons.org/licenses/by-nc-sa/3.0/. All other uses must be approved by the author(s) or EPAA. EPAA is published by the Mary Lou Fulton Institute and Graduate School of Education at Arizona State University Articles are indexed in CIRC (Clasificación Integrada de Revistas Científicas, Spain), DIALNET (Spain), Directory of Open Access Journals, EBSCO Education Research Complete, ERIC, Education Full Text (H.W. Wilson), QUALIS A2 (Brazil), SCImago Journal Rank; SCOPUS, SOCOLAR (China).

Please send errata notes to Gustavo E. Fischman fischman@asu.edu

Join EPAA's Facebook community at https://www.facebook.com/EPAAAAPE and Twitter feed@epaa_aape.
\end{abstract}




\section{education policy analysis archives editorial board}

Lead Editor: Audrey Amrein-Beardsley (Arizona State University)

Editor Consultor: Gustavo E. Fischman (Arizona State University)

Associate Editors: David Carlson, Lauren Harris, Eugene Judson, Mirka Koro-Ljungberg, Scott Marley, Molly Ott, Iveta Silova (Arizona State University)

\author{
Cristina Alfaro \\ San Diego State University \\ Gary Anderson \\ New York University \\ Michael W. Apple \\ University of Wisconsin, Madison \\ Jeff Bale \\ University of Toronto, Canada \\ Aaron Bevanot SUNY Albany \\ David C. Berliner \\ Arizona State University \\ Henry Braun Boston College \\ Casey Cobb \\ University of Connecticut \\ Arnold Danzig \\ San Jose State University \\ Linda Darling-Hammond \\ Stanford University \\ Elizabeth H. DeBray \\ University of Georgia \\ David E. DeMatthews \\ University of Texas at Austin \\ Chad d'Entremont Rennie Center \\ for Education Research \& Policy \\ John Diamond \\ University of Wisconsin, Madison \\ Matthew Di Carlo \\ Albert Shanker Institute \\ Sherman Dorn \\ Arizona State University \\ Michael J. Dumas \\ University of California, Berkeley \\ Kathy Escamilla \\ University ofColorado, Boulder \\ Yariv Feniger Ben-Gurion \\ University of the Negev \\ Melissa Lynn Freeman \\ Adams State College \\ Rachael Gabriel \\ University of Connecticut
}

Amy Garrett Dikkers University

of North Carolina, Wilmington

Gene V Glass

Arizona State University

Ronald Glass University of

California, Santa Cruz

Jacob P. K. Gross

University of Louisville

Eric M. Haas WestEd

Julian Vasquez Heilig California

State University, Sacramento

Kimberly Kappler Hewitt University of North Carolina Greensboro

Aimee Howley Ohio University

Steve Klees University of Maryland

Jaekyung Lee SUNY Buffalo

Jessica Nina Lester

Indiana University

Amanda E. Lewis University of

Illinois, Chicago

Chad R. Lochmiller Indiana

University

Christopher Lubienski Indiana

University

Sarah Lubienski Indiana University

William J. Mathis

University of Colorado, Boulder

Michele S. Moses

University of Colorado, Boulder

Julianne Moss

Deakin University, Australia

Sharon Nichols

University of Texas, San Antonio

Eric Parsons

University of Missouri-Columbia

Amanda U. Potterton

University of Kentucky

Susan L. Robertson

Bristol University
Gloria M. Rodriguez

University of California, Davis

R. Anthony Rolle

University of Houston

A. G. Rud

Washington State University

Patricia Sánchez University of

University of Texas, San Antonio

Janelle Scott University of

California, Berkeley

Jack Schneider University of

Massachusetts Lowell

Noah Sobe Loyola University

Nelly P. Stromquist

University of Maryland

Benjamin Superfine

University of Illinois, Chicago

Adai Tefera

Virginia Commonwealth University

A. Chris Torres

Michigan State University

Tina Trujillo

University of California, Berkeley

Federico R. Waitoller

University of Illinois, Chicago

Larisa Warhol

University of Connecticut

John Weathers University of

Colorado, Colorado Springs

Kevin Welner

University of Colorado, Boulder

Terrence G. Wiley

Center for Applied Linguistics

John Willinsky Stanford University

Jennifer R. Wolgemuth

University of South Florida

Kyo Yamashiro

Claremont Graduate University

Miri Yemini

Tel Aviv University, Israel 


\section{archivos analíticos de políticas educativas consejo editorial}

Editor Consultor: Gustavo E. Fischman (Arizona State University)

Editores Asociados: Armando Alcántara Santuario (Universidad Nacional Autónoma de México), Angelica Buendia, (Metropolitan Autonomous University), Alejandra Falabella (Universidad Alberto Hurtado, Chile), Antonio Luzon, (Universidad de Granada), José Luis Ramírez, (Universidad de Sonora), Paula Razquin (Universidad de San Andrés), Maria Alejandra Tejada-Gómez (Pontificia Universidad Javeriana, Colombia)

Claudio Almonacid

Universidad Metropolitana de

Ciencias de la Educación, Chile

Miguel Ángel Arias Ortega

Universidad Autónoma de la

Ciudad de México

Xavier Besalú Costa

Universitat de Girona, España

Xavier Bonal Sarro Universidad Autónoma de Barcelona, España

Antonio Bolívar Boitia

Universidad de Granada, España

José Joaquín Brunner Universidad Diego Portales, Chile

Damián Canales Sánchez Instituto Nacional para la Evaluación de la Educación, México

Gabriela de la Cruz Flores

Universidad Nacional Autónoma de México

Marco Antonio Delgado Fuentes Universidad Iberoamericana, México

Inés Dussel, DIE-CINVESTAV, México

Pedro Flores Crespo Universidad Iberoamericana, México
Ana María García de Fanelli

Centro de Estudios de Estado y

Sociedad (CEDES) CONICET, Argentina

Juan Carlos González Faraco

Universidad de Huelva, España

María Clemente Linuesa

Universidad de Salamanca, España

Jaume Martínez Bonafé

Universitat de València, España

Alejandro Márquez Jiménez

Instituto de Investigaciones sobre la Universidad y la Educación, UNAM, México

María Guadalupe Olivier Tellez, Universidad Pedagógica Nacional, México

Miguel Pereyra Universidad de Granada, España

Mónica Pini Universidad Nacional de San Martín, Argentina

Omar Orlando Pulido Chaves Instituto para la Investigación Educativa y el Desarrollo Pedagógico (IDEP) José Ignacio Rivas Flores Universidad de Málaga, España

\author{
Miriam Rodríguez Vargas \\ Universidad Autónoma de \\ Tamaulipas, México \\ José Gregorio Rodríguez \\ Universidad Nacional de Colombia, \\ Colombia \\ Mario Rueda Beltrán Instituto de \\ Investigaciones sobre la Universidad \\ y la Educación, UNAM, México \\ José Luis San Fabián Maroto \\ Universidad de Oviedo, \\ España
}

Jurjo Torres Santomé, Universidad de la Coruña, España

Yengny Marisol Silva Laya

Universidad Iberoamericana, México

Ernesto Treviño Ronzón

Universidad Veracruzana, México

Ernesto Treviño Villarreal

Universidad Diego Portales

Santiago, Chile

Antoni Verger Planells

Universidad Autónoma de

Barcelona, España

Catalina Wainerman

Universidad de San Andrés, Argentina

Juan Carlos Yáñez Velazco

Universidad de Colima, México 


\section{arquivos analíticos de políticas educativas conselho editorial}

Editor Consultor: Gustavo E. Fischman (Arizona State University)

Editoras Associadas: Kaizo Iwakami Beltrao, (Brazilian School of Public and Private Management - EBAPE/FGV, Brazil), Geovana Mendonça Lunardi Mendes (Universidade do Estado de Santa Catarina), Gilberto José Miranda, (Universidade Federal de Uberlândia, Brazil), Marcia Pletsch, Sandra Regina Sales (Universidade Federal Rural do Rio de Janeiro)

\author{
Almerindo Afonso \\ Universidade do Minho \\ Portugal \\ Rosanna Maria Barros Sá \\ Universidade do Algarve \\ Portugal

\section{Maria Helena Bonilla \\ Universidade Federal da Bahia \\ Brasil}

Rosa Maria Bueno Fischer

Universidade Federal do Rio Grande do Sul, Brasil

\section{Alice Casimiro Lopes \\ Universidade do Estado do Rio de \\ Janeiro, Brasil}

\section{Suzana Feldens Schwertner \\ Centro Universitário Univates \\ Brasil}

Flávia Miller Naethe Motta

Universidade Federal Rural do Rio de Janeiro, Brasil

\section{Alexandre Fernandez Vaz \\ Universidade Federal de Santa \\ Catarina, Brasil \\ Regina Célia Linhares Hostins \\ Universidade do Vale do Itajaí, Brasil}

\section{Alfredo Macedo Gomes \\ Universidade Federal de Pernambuco}

Brasil

\section{Jefferson Mainardes}

Universidade Estadual de Ponta

Grossa, Brasil

\section{Jader Janer Moreira Lopes \\ Universidade Federal Fluminense e \\ Universidade Federal de Juiz de Fora, Brasil \\ Debora Nunes \\ Universidade Federal do Rio Grande do Norte, Brasil}

\section{Alda Junqueira Marin \\ Pontifícia Universidade Católica de São Paulo, Brasil}

\section{Dalila Andrade Oliveira}

Universidade Federal de Minas

Gerais, Brasil
José Augusto Pacheco

Universidade do Minho, Portugal

Jane Paiva

Universidade do Estado do Rio de

Janeiro, Brasil

Paulo Alberto Santos Vieira

Universidade do Estado de Mato

Grosso, Brasil

Fabiany de Cássia Tavares Silva

Universidade Federal do Mato

Grosso do Sul, Brasil

António Teodoro

Universidade Lusófona

Portugal

\section{Lílian do Valle}

Universidade do Estado do Rio de Janeiro, Brasil

\section{Alfredo Veiga-Neto}

Universidade Federal do Rio Grande do Sul, Brasil 